\title{
Critical Discourse Analysis of News Headline about Imran Khna's Peace March towards Wazaristan
}

\author{
Farhat Sajjad \\ National University of Modern Languages, Islamabad Pakistan.
}

\begin{abstract}
The current study is aimed at critical discourse analysis of the news headlines about Imran Khan's peace march towards Waziristan. Twenty news headlines were randomly selected from local English papers, local Urdu papers and foreign English papers. The critical discourse analysis of research data elucidated how a single news item was differently presented in different newspapers based on the ideological perspectives of their editors. The local papers aimed at highlighting the political dimension of peace march and it tried to focus on the criticism raised by the politicians against Imran Khan while the foreign papers adopted a more direct approach by advocating the issue of drone attacks and criticizing the role of Pakistani government policies in creating hindrances in the march. Another significant point of foreign media was the specific focus on the participation of Americans in peace march termed as "protest against drone attacks" by the press. The study concludes that news are representation of editor's ideologies and it depicts their political, personal and national inclination in spite of their claim to be unbiased and neutral in their approach.
\end{abstract}

Key words: News Headlines, peace march, drone attacks, ideology, critical discourse analysis

\section{Introduction}

Today we are living in the world of fast communication where all social events become public through different sources such as media and other technological means. In fact media plays a key role in transforming simple social events in the form of news and most of the time it manipulates information according to its own interest. Central to news is the language through which social events are described and now- a -days language is not considered as a simple way of interpreting reality rather it constructs reality (Taiwoo, 2007). News papers are considered as a strong mean of presenting social and national issues in terms of their own ideological perspectives. News headlines are most important part of newspapers as they provide a quick mode of information to the ones who can not spare time for reading the details of news item (Mahmood \& Javed 2011).The focus of the current study is news headlines as they are important in constructing ideologies of masses and the second main concern of the study is to highlight the differences in the news representation of foreign and local media with special reference to their ideological perspectives.

\section{1: Research questions}

i) To what extent ideologies are constituted through media text?

ii) How do foreign and local media present the same news item differently with respect to their own ideological perspectives?

\section{2: Research objectives}

The objectives of this study are

- To figure out how does media constitutes ideologies?

- To highlight the differences in the way foreign and local media present same news item with respect to their ideological perspectives

\section{3: Significance of the study}

The current study will provide assistance in developing a clear understanding of the hidden ideologies in apparently seeming simple text for the newspaper readers. As in the study the news of Imran khan's peace march towards Waziristan was addressed which is a national issue and I have focused on the role of local and foreign both media in the representation of same news in different ways. The study will help future researchers to explore the significance of newspaper headlines in order to find out how it affects the ideologies of masses and constructs reality in social and political context.

\section{Literature review}

The literature review of the study will serve as the theoretical framework for the research methodology. 


\subsection{Critical discourse analysis}

CDA has appeared as one of the most effective approach for analysis of discursive power relations over the last few decades. The emancipatory agenda of CDA is to analyze the opaque power relations in order to highlight the hidden ideologies embedded in it (Fairclough, 1993). CDA aims at making the connections transparent among discourse practices, social practices and social structures, connections that might be opaque to the layperson (Sheyholislami 2001). By keeping in mind both these views it can be said that the agenda of CDA is very clear and elaborative as it is concerned not only with the social practices but with the social structures i.e. order of discourse, another significant dimension of CDA is to reveal power relations through certain techniques and ways.

According to Van Dijk (1988) the main concern of media is to analyze the language used in a discourse to highlight the sources of power, dominance, and inequality with special reference to social, political and historical context. Wodak adopted a different approach for the analysis of discourse as the focal point in her theory is the role of historical perspective i.e., text never stands in isolation rather it always has some link with some other text in the history the same phenomenon is termed as intertextuality by Fairclough who talks about relationship of one text with the other genres of social practice. According to Wodak and Ludwig (1999) same communicative event i.e. text, might be interpreted differently by the readers and the listeners depending on their social and personal context and their background knowledge. Fairclough brought into light some other methodological concerns where the Interdiscursivity and intertextuality were given more significance (Sheyholislami 2001). According to Fowler el, 1991 the linguistic choices are directly linked with the ideological assumption.

\section{2: CDA OF MEDIA:}

CDA has been applied to different domains of discourse for a comprehensive analysis of written and spoken both text. Media discourse is also an important domain with respect to social, political and historical context and currently CDA has provided a good platform for a detailed analysis.

Van Dijk presented socio-cognitive model for the interpretation of media discourse according to him media text represents the ideological assumptions of news producers depending on their cultural, political and social background (Van Dijk, 1998).Media discourse is not a simple text which can be comprehended easily rather apparently seeming simple text carry very complicated meanings especially in the case of print media i.e. newspapers. The analysis of news text has been an important practice in studies of discourse analysis as Van Dijk (1991) analyzed newspaper reports in order to figure out the significance of their roles in developing ethnic relations. Afterwards many other researchers such as Kress (1990) discussed the embedded ideological assumptions in discursive social structures. As discussed earlier in the study that newspaper editors represents social events in their own ideological framework and resultantly it can be stated that news are biased and they cannot be neutral. According to Olowe, 1993(as cited in Taiwoo)

"The editor and his reporters on the one hand and their audience constitute an ideological empire. The newspaper subjects all newsworthy events that constantly come up in social life to rigorous linguistic manipulation to make them suit the ideological expectation of the audience (p.8)".

It means that ideologies are related to the social events in the society and the linguistic choices of news producers' affect them to a large extent. According to Giltin (2003) mass media produces ideology through pictures, symbols and rhetoric as they appear in the newspaper.

\section{Research methodology}

The data for the current study has been collected from twenty local English, local Urdu and international English newspaper. The news for the study is randomly selected from $6^{\text {th }}$ October 2012 to $10^{\text {th }}$ October 2012. The research objectives are to find out the different representations of the same news item in local and foreign media. The research data is analyzed through CDA of media .I have used Van Dijk's approach of media text analysis along with Olowe's techniques for analysis of newspaper headline. News headlines are analyzed from four aspects at linguistic level i.e., passivization, Topicalization, information, evaluation and judgement. The second analysis is done at surface level.

\section{Data analysis and discussion}

Surface structure classification of news headlines:

\section{1: Plain headlines}

Plain headlines refers to simple statement about a social event in newspapers .As the current study has used CDA as the research method and the agenda of CDA of Media is to find out the hidden meanings in seemingly simple or plain text.The text used for media discourse apparently look simple but it always carry 
complex ideological perspectives. In these news about peace march of Imran khan towards Waziristan the key word " drones " has been used differently in foreign and local both media.

\section{- Thousands of Pakistanis rally against US drones strikes (The Guardians $7^{\text {th }}$ October 2012)}

Here the news is produced by UK newspaper and unlike US newspapers the editor has openly used the word "US drones strikes " and the important point is the participation of a large number of Pakistanis i.e. there were no foreigners in the march. While the next news in a Pakistani newspaper will reveal the hidden agenda of UK government who restricted its citizens to participate in the rally .Now this ideology of the editor is implicit and it became clear to us by CDA which justifies the same fact as said by Taiwoo (2007)" Regular aspects of media messages such as news reports, headlines, advertisements, editorials, features, etc are often subjected to linguistic manipulations ".It means that headlines are manipulated by the editors to hide certain facts .

- UK restricts its citizens to join PTI peace march toward Waziristan (The Nation $7^{\text {th }}$ October 2012)

The same news of peace march is presented in a totally new scenario by The Nation, a renowned Pakistani English newspaper who indirectly criticized the policy of UK government who did not allow its citizen to take part in the march. This news was not highlighted by any UK newspaper because the government policy was aimed at highlighting only those aspects of news which are favourable for their own point of view. Interestingly the editor has used here a very positive word i.e." peace march" unlike many other foreign newspaper who focused upon using different terms such as "strikes ", convoy", "anti-drones attack march " etc .

4.2: Speech as headlines:

In this technique of headline analysis direct or reported speech of the person is used and in most of the cases names are also mentioned which makes the authenticity of the news more high.

- Imran's Peace March gets special US media coverage (The Nation $9^{\text {th }}$ October 2012).

This headline from a Pakistani English newspaper has focused upon the role of other media forces in terms of their attitude towards the peace march." US media coverage" makes it explicit that US has given special significance to this peace march as it is directly linked to drone attacks and role of American government in this whole scenario. Apart from this aspect another important factor over here is the significant value of peace march at international level .

- Imran's drone protest ends in U-turn (The Age $8^{\text {th }}$ October 2012)

Interestingly Australian media used a different word for the peace march and they termed it as a "protest" which ended in nothing and all the efforts which Imran khan made they become apparently futile. This headline can be analyzed in many different ways the one important aspect can be the failure of Imran Khan as a leader who couldn't complete his mission, the second aspect can be the role of Pakistani government who did not provide proper support to Imran khan due to many political factors and resultantly the whole efforts of Imran khan ended in nothing. Now these ideologies of media are not explicitly expressed here but still they became clear by using CDA which makes analyst take a stance and get an access to hidden ideologies in the text.

- Imran has plenty to rejoice about Pakistan (GULFNEWS, DUBAI, and 7th OCTOBER 2012)

The focus of the news here is on the optimistic approach of Imran khan as a leader although he could not get access to many areas of south but $\mathrm{s}$ Waziristan till he managed to visit lot of those places where nobody from government officials entered before him .Imran khan proved his strength by highlighting the issue of drone attacks at international level through this march. Here the ideology of editor is positive as the news is produced for the foreigners not for the natives.

- Imran wants to become a political martyr: Fazl (THE NEWS $7^{T H}$ OCTOBER 2012)

Quiet opposite to the foreign media the local media focused upon the political aspects of the news by quoting statements from politician such as in this news a renowned politician, Fazlur Rehman criticized Imran khan directly by using a mocking term "political martyr ". As this news is produced for the natives and the agenda of editors is to emphasize the political effects of all issues so consciously some key words such as peace march and anti-drone attack rally are omitted.

- Fazlur Rehman terms Imran Khan a "western agent" (DAWN $7^{T H}$ OCTOBER 2012)

This news also serves the same objectives as discussed in the previous news item, the local media highlights the criticism raised against Imran khan by other politicians. Here use of graphological devices such as quotation marks , use of upper case etc increases the significance of the words ." western agents " refers to a negative image of Imran khan as the peace march was an attempt to condemn the interference of western military in Waziristan. Interestingly the editor has used full names of both politicians i.e. Fazlur Rehman and Imran Khan so the conscious use of full their full names makes the authenticity of the news high.

- Imran didn't say anything new on drone attacks: Kaira (DAWN $8^{T H}$ OCTOBER 2012)

In this news item by Dawn news the political aspect of Imran khan's peace march are highlighted. Here the statement of a renowned politician, Qamar Zaman Kaira is discussed who is minister of information and broadcast in Pakistan, he passed quiet negative comments about Imran khan and his peace march rather instead of" peace march" the conscious use of " drone attacks " made the intensity of its sensitivity more high. According to this statement the minister of information thinks that Imran khan has not done something new 
about drone attacks rather the facts are already discussed by others. Now this news is produced for local masses so the context will be clear to them, i.e. the efforts of Imran khan are linked to political factors instead of taking them as a national issue.

- Imran Khan leads drone protesters into volatile Pakistan region (Los Angeles Times $6^{\text {th }}$ October 2012)

In this news headline the American newspaper have highlighted the negative attributes about Waziristan, the land of aggressive people. In this news headline a different aspect of peace march is discussed, here the focus in not on the peace march rather the "volatile "region i.e. i Waziristan is highlighted .

- Drone hamloon ka khilaf tehrike-e insaf ka aman march Daira Ismail Khan pohanch gya ,khatra Taliban se nahi Zardari aur Fazlur-Rehman se ha, Imran khan (JANG $7^{\text {th }}$ October 2012 ) peace march of PTI against drone attacks reached DI KHAN, danger is from Zardari and Fazlur-Rehman not from Taliban, Imran Khan .

This news headline was published in a national Urdu Pakistani newspaper, as the news was presented in the local newspaper so the political aspects are highlighted here Imran Khan discussed about his personal security issues and he talked about two leading political leaders ,President of Pakistan Mr. Asif Ali Zardari and Mr. Fazlur Rehman the chairperson of JUI .According to news headlines Imran Khan expressed his security concerns and he talked about the threats from the above mentioned leaders. Now this news item is produced for the local masses so the political conspiracy between PPP, JUI and PTI are not a new issue for them and they have a clear idea about the context of the news.

- Imran Khan ka aman march ...( DAILYAUSAF $7^{T H}$ OCTOBER 2012)

Another Pakistani local Urdu newspaper has used very positive terms about the peace march" man march". The news headline has consciously omitted the term drone attacks here and the ideology of editor over here is to develop the positive attitude of masses towards peace march and obviously about Imran Khan as well. In contrast to foreign media the local media has attempted to focus upon the positive aspects of peace march.

- March exposed US atrocities to world: Imran (The Frontier Post $7^{\text {th }}$ October 2012)

Like other Pakistani local newspaper the news headlines published in The Frontier Post also aimed at quoting statement form Imran khan which highlights his political agenda. The use of term "US atrocities" refers to all violent acts associated with American government's policy about, Waziristan as the news is produced for the local masses so the editor has adopted a different ideology i.e. a direct criticism raised against the Americans which is not a common practice of Pakistani national newspapers or international newspapers.

- Pakistani Taliban warn Imran Khan over 'peace march' into Waziristan (The INDEPENDENT $6^{T H}$ OCTOBER 2012)

In opposite to all other local and foreign newspapers the use of a different term "Pakistani Taliban " have presented a new dimension of peace march ,i.e. it is not the American military from which this peace march should feel insecure rather it is Pakistani Taliban who cause security issues for the participants of peace march . The conscious use of this term is aimed at developing a different ideology of foreign readers who thus get a negative picture of Pakistan in terms of "Pakistani Taliban" a synonym of terrorists. The news depicts the biased ideology of the editor and thus it also aims at creating mis understanding among masses also.

\section{3: Headlines with pointers}

In these types of news headlines the information is elaborated by a pointer i.e. the headlines consists of two parts. The first part carries such words which make reader aware about the comments discussed in the news later on. These headlines serve a very important function with reference to the representation of political inclination of the news editors.

- Khan to rally against CIA drones (FINANCIAL TIMES $5^{\text {TH }}$ OCTOBER 2012)

This news headline published in a UK based newspaper has presented a totally new dimension of peace march it has tried to link drone attacks with CIA i.e. Central Intelligence Agency of Pakistan, now this is a strange fact because through international media and political discourse between Pakistan and America it became explicit that drone attacks are controlled by American troops in Pakistan and they are not linked to Pakistani military. The point to be noted over here is the biased attitude of UK media who has attempted to mis represents reality for international readers who may not get a direct access to the political and national issues of Pakistan, so resultantly the international reader may get a negative picture of Pakistani CIA. The ideology of editor is aimed at misleading the masses in this headline and the readers who do not read the complete news they may not be able to get to know the facts by analyzing the news headline.

- PTI peace march: Western voices add swagger to rally (THE EXPRESS TRIBNUE 8TH OCTOBER 2012)

The news published in a local Pakistani newspaper was aimed at presenting a new aspect of peace march, the emphasis of the editor is on the participation of western citizen in the rally and the disproval of drone attacks by them (western citizen) added up more value to the peace march.

- Pakistani military blocks Imran Khan's anti-US protest in tribal region (THE ECONOMIC TIME $7^{\text {TH }}$ OCTOBER 2012) 
An Indian newspaper took a different position by doing a direct criticism on the Pakistani military that caused hindrance to peace march. The ideological perspective of editor is totally different here as the use of "anti-US protest" presents a different picture of the peace march where the conscious omission of drone attacks makes the facts very blurred for the foreign readers who may not be able to get a clear idea of the event.

- Pakistan warns it will halt Imran Khan-led protest against drone strikes (The Australian news $7^{\text {th }}$ October 2012)

The stance took by the Australian newspaper is misleading for the foreign readers as the news presents an idea that it is Pakistani government who creates hindrances in the peace march which is not true. The foreign media has attempted to blurred facts by portraying the role of government in a negative context.

- Americans in Pakistan to protest drone strikes (BloombergBusinessweek News $5^{\text {th }}$ October 2012)

A local Pakistani English newspaper has highlighted the participation of Americans in the protest against the drone attacks. Here the ideology adopted by the editor is highlight the significance of the event i.e. participation of Americans in the peace march which is termed as protest. This news headline is very important because if we look at the context of the drone attacks it becomes clear that they are linked with American military and the protest of Americans against the brutal act of their own country is a very different phenomenon in the international politics.

- Code Pink activists warned of possible terrorist strike against anti-drone rally in Pakistan (Anchorage Daily News $5^{\text {th }}$ October 2012)

The news headline from Alaska newspaper has used a different term i.e. code pink activist , a well renowned group in America which aims at promoting peace activities and advocating against all disruptive acts of American government . The presence of code pink activist in Waziristan is a great news because Waziristan is a place where no western can not think even to go now the news of security threats for pink code activist is really a big question mark for the Pakistani government and the ideology of editor is explicit here. As the news is produced for the foreign reader so the issue of security and threats for the American peace activist has portrayed not a very positive image of Pakistan, a land where foreigners can not safely move. Consequently the foreign reader will also develop the same ideology as presented by the editor.

- Americans ignore 'great risks,' travel to Pakistan to protest US drone strikes (bnc NEWSPAPER 5TH OCTOBER 2012)

Another American newspaper has portrayed a positive image of Americans as daring nation who ignored all the risk and took part in the protest against US drone attacks. As the news is produced for the foreign readers so the editor has consciously presented a positive ideological perspective of US in the context of its participation in the anti drone rally.

\section{Linguistic features of headlines in presenting ideologies}

There are certain linguistic features of the headlines of Imran Khan's peace march towards Waziristan which depicts the ideologies of different newspapers.

\section{1: Topicalization}

Topicalization is an important feature of news headline and it serves as a true marker for the depiction of the ideology of the news editors. In this study the headlines produced for the local media has depicted the elements of political inclinations and those words are used topicialized which serve the above mentioned purpose .

- Drone hamloon ka khilaf tehrike-e insaf ka aman march Daira Ismail Khan pohanch gya ,khatra Taliban se nahi Zardari aur Fazlur-Rehman se ha, Imran khan (JANG $7^{\text {th }}$ October 2012 ) peace march of PTI against drone attacks reached DI KHAN, danger is from Zardari and Fazlur-Rehman not from Taliban, Imran Khan

- Imran wants to become a political martyr: Fazl (THE NEWS $7^{T H}$ OCTOBER 2012)

- Fazlur Rehman terms Imran Khan a "western agent" (DAWN $7^{T H}$ OCTOBER 2012)

- Imran didn't say anything new on drone attacks: Kaira (DAWN $8^{T H}$ OCTOBER 2012)

- Imran Khan ka aman march ...( DAILYAUSAF $7^{T H}$ OCTOBER 2012),Imran Khan's peace march

Here the ideology of the news editor is to present the political aspect of peace march and the political conspiracy between different parties is highlighted here.

\section{2: Passivization}

It is an important element of news headlines where the news agency is consciously deleted in order to create curiosity among readers and to develop certain assumption along with providing a chance to make more subjective and biased interpretation of the news items. In the current study in many local and foreign newspapers headlines the agency is missing. 
- Code Pink activists warned of possible terrorist strike against anti-drone rally in Pakistan (Anchorage Daily News $5^{\text {th }}$ October 2012)

- Imran's drone protest ends in U-turn (The Age $8^{\text {th }}$ October 2012)

- Khan to rally against CIA drones (FINANCIAL TIMES $5^{\text {TH }}$ OCTOBER 2012)

- Thousands of Pakistanis rally against US drones strikes (The Guardians $7^{\text {th }}$ October 2012)

The headline of Anchorage newspaper have consciously omitted the agency here and the readers may not be able to get an idea about who have warned American code pink activist to avoid participation in peace march, same practice is carried on in the other news headlines quoted here the ideology of the editor can be analyzed through adjectives used in headlines such as martyr, swagger, atrocities and volatile presents different positive and negative ideological assumptions. The word "martyr" was sued in a negative context by Fazlur Rehman for Imran Khan. And in another news headline "volatile" was used in a negative context for Pakistani tribal areas by a foreign newspaper and for American government" atrocities" was used by Imran Khan in a local newspaper.

\section{3: Information}

Another important factor of new headlines is the information carried by the news .in the current study the information provided by local and foreign newspapers after the peace march of Imran Khan presents different ideologies of editors.

- Pakistani military blocks Imran Khan's anti-US protest in tribal region (THE ECONOMIC TIME $7^{\text {TH }}$ OCTOBER 2012

- Pakistani Taliban warn Imran Khan over 'peace march' into Waziristan (The INDEPENDENT $6^{\text {TH }}$ OCTOBER 2012)

- Pakistan warns it will halt Imran Khan-led protest against drone strikes (The Australian news $7^{\text {th }}$ October 2012)

- Imran didn't say anything new on drone attacks: Kaira (DAWN $8^{T H}$ OCTOBER 2012)

As the agenda of CDA is to reveal the hidden ideologies of the media text so by looking at the information provided by the news headlines the apparently seeming simple words are a doorway to the complex ideologies .such as the headlines mentioned above show the hindrances created by the Pakistani military in peace march, the significant point to be noted here is that all these newspapers are foreign.

\section{4: Evaluations and judgments}

In the analysis of media text especially the news headlines an important element is the choice of news by the editors. The news editors select only those items which create sensation among readers and ultimately make them read the whole news such as the following headlines support the same philosophy.

- Americans in Pakistan to protest drone strikes (BloombergBusinessweek News $5^{\text {th }}$ October 2012)

- Pakistani Taliban warn Imran Khan over 'peace march' into Waziristan (The INDEPENDENT $6^{\text {TH }}$ OCTOBER 2012)

- UK restricts its citizens to join PTI peace march toward Waziristan (The Nation $7^{\text {th }}$ October 2012)

\section{Conclusion}

The study examined how ideologies are constructed through news headlines by working within the framework of CDA of Media .It was concluded that the local and foreign both media have given special coverage to the news of imran khans peace march towards Waziristan as it was a big news in international politics ,a significant aspect of news headlines was special emphasis on the participation of American peace activist by the foreign media because America is directly linked with the drone attacks while the local media presented those aspect of peace march which lead towards national political issues by quoting criticism of renowned politicians against Imran Khan .Over all the use of speech as headline was maximum practice in foreign and local both media as it increases the authenticity of the news. The foreign media focused much on role of Pakistani military forces which according to many foreign news papers caused hindrances in the peace march.

The whole study can be summed up by saying that CDA enables analyst to reveal the hidden ideologies in apparently seeming plain text which is not possible otherwise.

\section{References:}

[1] Dijk, V. (1988). News as Discourse. New Jersey \& London: Lawrence Earlbaum Associates Publication

[2] Develotte, C., \& Rechniewski, E. (2001). Discourse analysis of newspaper headlines: A methodological framework for research into national representations. Web Journal of French Media Studies Volume 4, Number 1, Accessed on October $27^{\text {th }} 2012$ from http://wjfms.ncl.ac.uk/joed4.htm.

[3] Dijk, V. (1988). News as Discourse. New Jersey \& London: Lawrence Earlbaum Associates Publication

[4] Dijk, V. (2000).Ideology and discourse -A Multidisciplinary Introduction. Pompeu Fabra University, Barcelona. 
[5] Fairclough, N. (2000). Language and Power. $2^{\text {nd }}$ edition. New York.

[6] Izadi,F, F \& Saghaye-Biria, L. (2000) A Discourse Analysis of Elite American Newspaper Editorials The Case of Iran's Nuclear Program. Journal of communication inquiry, volume 31 number 2, pg no 140-165. Sage publications accessed on $26^{\text {th }}$ October 2012. http://jci.sagepub.com.

[7] Olowe J. (1993) Language and Ideology in Nigerian Newspapers in the English Medium. An Unpublished Ph.D. Thesis, Obafemi Awolowo University Ile-Ife.

[8] P. López-Rabadán \& A. Casero-Ripollés (2012): "Evolution of the Spanish media agenda (1980-2010). Longitudinal analysis of the front pages of two of the most important Spanish newspapers", at Revista Latina de Comunicación Social, 67. La Laguna (Tenerife): La Laguna University, pages 459 to 480 retrieved on $30^{\text {th }}$ October 2012 from http://www.revistalatinacs.org/067/art/964_Castellon/20_Caseroen.html

[9] Sheyholislami, J. (2001). Critical discourse analysis. Accessed on $28^{\text {th }}$ October 2012 from http://httpserver. carleton.ca/ jsheyhol/CDA.htm.

[10] Taiwo R. (2004) "Speech as Headline in Nigerian Newspapers", in Segun Awonusi and E. A. Babalola, eds The Domestication of English in Nigeria. (Lagos: University of Lagos Press 2004. 323 -335).

[11] Wodak, R. (1989) Language, Power and Ideology. Amsterdam: Benjamins.

[12] Retrieved from http://www.adn.com/2012/10/05/2651727/code-pink-activists-warned-of.html retrieved on $16^{\text {th }}$ October 2012.

[13] Retrieved from http://worldnews.nbcnews.com/_news/2012/10/05/14241712-americans-ignore-great-risks-travel-to-pakistan-toprotest-us-drone-strikes retrieved on

[14] $16^{\text {th }}$ October 2012

[15] Retrieved from http://www.thenews.com.pk/Todays-News-13-17998-Imran-should-hold-talks-with-Taliban-Kaira retrieved on $16^{\text {th }}$ October 2012

[16] Retrieved from http://dawn.com/2012/10/08/imran-didnt-say-anything-new-on-drone-attacks-kaira/ retrieved on $16^{\text {th }}$ October 2012

[17] Retrieved from http://dawn.com/2012/10/08/imran-didnt-say-anything-new-on-drone-attacks-kaira/ retrieved o $16^{\text {th }}$ October 2012

[18] Retrieved from http://gulfnews.com/news/world/pakistan/imran-has-plenty-to-rejoice-about-1.1086405Imran Khan's anti-drone protest falls short of destination http://www.telegraph.co.uk/news/worldnews/asia/pakistan/9592632/Imran-Khans-anti-drone-protest-falls-short-of-destination.html retrieved on $16^{\text {th }}$ October 2012

[19] Retrieved from http://www.theage.com.au/world/imrans-drone-protest-ends-in-uturn-20121008-277w5.htm retrieved on $16^{\text {th }}$ October 2012

[20] Retrieved from http://economictimes.indiatimes.com/news/politics/nation/pakistani-military-blocks-imran-khans-anti-us-protest-intribal-region/articleshow/16712318.cms retrieved on $16^{\text {th }}$ October 2012

[21] Retrieved from Imran's Peace March gets special US media coverage | The Nation www.nation.com.pk/...news-newspaper.../imrans-peace-march-gets-s...Cached retrieved on $16^{\text {th }}$ October 2012

[22] Retrievedfromhttp://www.dailyausaf.com/epaper/wp-content/uploads/2012/October/07/p14.jpg http://dailyausaf.com/epaper/?pg=14 retrieved on $16^{\text {th }}$ October 2012

[23] Retrieved from http://www.independent.co.uk/news/world/asia/pakistani-taliban-warn-imran-khan-over-peace-march-intowaziristan-8200048.html retrieved on $16^{\text {th }}$ October 2012

[24] Retrieved from http://www.ft.com/cms/s/0/8a25d184-0efd-11e2-9343-00144feabdc0.html\#axzz28YV9XOgo retrieved on $16^{\text {th }}$ October 2012

[25] Retrieved from http://latimesblogs.latimes.com/world_now/2012/10/imran-khan-leads-caravan-to-pakistans-volatile-northwest-toprotest-us-drone-strikes-.html retrieved on $16^{\text {th }}$ October 2012

[26] Retrieved from http://tribune.com.pk/story/448544/pti-peace-march-western-voices-add-swagger-to-rally/ retrieved on $16^{\text {th }}$ October 2012 